\title{
A SIMPLE, RAPID METHOD FOR PREPARATION OF VIRUS ISOLATES FROM CELL CULTURE FOR ELECTRON MICROSCOPY
}

\author{
D. E. Skilling, J. E. Barlough, E. S. Berry, ${ }^{1}$ and A. W. Smith \\ Calicivirus Research Laboratory, College of Veterinary Medicine, Oregon State University, \\ Corvallis, Oregon 97331-4802
}

\begin{abstract}
Summary: A simple procedure for the rapid preparation of virus isolates from cell culture for negative-contrast electron microscopy was devised. Using only conventional centrifugation steps (i.e. without ultracentrifugation), the procedure produced consistent, fine-quality preparations of a variety of virus types differing in size/shape and buoyant density.
\end{abstract}

Key words: virus isolates; cells, cultured; electron microscopy; centrifugation.

\section{INTRODUCTION}

Negative-contrast electron microscopy (NCEM) is a simple and efficacious means of visualizing viruses present in cell culture supernatants and in clinical specimens of various kinds $(1,2,7,12,21)$. Several NCEM approaches for improved results involving concentration of samples by centrifugation have been described $(7,8,13,17,22,23)$. Conventional methods have utilized preparatory low-speed centrifugation (clarification) to remove unwanted debris, followed by ultracentrifugation to pellet virus particles $(6-$ $8,11,21,23)$.

We report here a simple and rapid procedure for the preparation of virus particles from cell culture material for NCEM that eliminates the need for an ultracentrifugation step. This technique is used routinely in our laboratory and has proven to be extremely useful for the rapid detection of viruses present in small quantities of cell culture material.

\section{MATERIALS}

A. Cell culture

Minimum essential medium Eagle, with Earle's balanced salt solution without L-glutamine, No. 12 125Y, M.A. Bioproducts ${ }^{1}$

HyClone ${ }^{\text {TY }}$ fetal bovine serum, Lot no. 100418 , HyClone Laboratories ${ }^{2}$

L-Glutamine $(100 \times)$, No. 320-5030, GIBCO ${ }^{3}$

Penicillin-streptomycin solution, No. 600-5070

Gentamycin sulfate, No. G-7632, Sigma $^{4}$

Trypsin-EDTA (1X), No. 610-5300

Culture tubes, polystyrene, $16 \times 125 \mathrm{~mm}$, No. 25200, Corning ${ }^{5}$

\footnotetext{
${ }^{I}$ To whom correspondence should be addressed
}

Shel-lab incubator, $\mathrm{CO}_{2}$, dual-chamber, No. 350 , Sheldon ${ }^{6}$

Roller drum, No. 1240, Lab-line ${ }^{7}$

B. Centrifugation

Freezer, biological, to $-90^{\circ} \mathrm{C}$, No. 8326. Forma ${ }^{8}$

Vortex mixer, No. $1290^{7}$

Conventional centrifuge, No. UV, IEC ${ }^{9}$

Micro tubes, polypropylene, $43 \times 10 \mathrm{~mm}, \mathrm{~N}_{0}$. 72.692, Sarstedt ${ }^{10}$

Bench-top centrifuge, CENTRA ${ }^{\mathrm{R}}-4$, No. $2382^{9}$, equipped with model IEC 817 fixed-angle rotor ${ }^{9}$

C. Electron microscopy

MILLI-Q ${ }^{R}$ Water Purification System, Millipore ${ }^{\prime \prime}$

Parafilm ${ }^{\mathrm{R}}$, American Can ${ }^{12}$

Grids, 300C (300 mesh, copper), Ted Pella'

Formvar solution $(0.5 \%)$, No. 01582, Electron Microscopy Sciences ${ }^{14}$

Phosphotungstic acid (1.5\%, pH 7.0), No. $19403^{13}$

Folded filter paper, $18.5 \mathrm{~cm}$, No. 12, Whatman ${ }^{15}$

Germicidal lamp, No. G30T8, GTE Sylvania ${ }^{16}$

Transmission electron microscope, No. EM 300 , Philips ${ }^{17}$

\section{PROCEDURE}

1. Passage clinical materials into culture tubes containing appropriate cell monolayers and $1.5 \mathrm{ml}$ cell culture medium.

2. Incubate tubes at $37^{\circ} \mathrm{C}$ on a roller drum $(0.33 \mathrm{rpm})$ until $4+$ cytopathic effect is observed.

3. Harvest cultures by one or more freeze-thaw cvcles $\left(-70^{\circ} \mathrm{C}\right)$.

4. Vortex cultures and clarify at $850 \times g$ for $10 \mathrm{~min}$ (room temperature) in a conventional centrifuge.

5. Transfer supernatants to polypropylene micro tubes 
and centrifuge at $2500 \times g$ for $10 \mathrm{~min}$ (room temperature) in a CENTRA ${ }^{R}-4$ bench-top centrifuge equipped with a model IEC 817 fixed-angle rotoi.

6. Transfer supernatants to fresh micro tubes and respin at $8850 \times g$ for $20 \mathrm{~min}$ (room temperature) in the CENTRA ${ }^{\mathrm{R}}-4$.

7. Resuspend pellets in $10 \mu \mathrm{l}$ sterile-filtered distilled water.

8. Transfer one drop of each sample to Parafilm ${ }^{\mathrm{R}}$.

9. Float individual Formvar-coated copper grids for 2 min on each drop, then blot dry with filter paper.

10. Touch each grid to a drop of sterile-filtered distilled water, then blot dry with filter paper.

11. Float each grid for $1 \mathrm{~min}$ on a drop of $1.5 \%$ phosphotungstic acid ( $\mathrm{pH} 7.0$ ), then remove excess stain with filter paper.

12. Leave all grids under ultraviolet light for at least 15 to $20 \mathrm{~min}$
13. Examine grids with an electron microscope at an accelerating voltage of $80 \mathrm{kV}$.

\section{DISCUSSION}

Viruses of infected cell cultures identified by NCEM have included members both of DNA (Adenoviridae, Herpesviridae, Poxviridae) and RNA (Picornaviridae, Caliciviridae, Coronaviridae, Reoviridae, Paramyxoviridae) virus families (Fig. 1). This technique has permitted detection of a wide variety of viral agents differing in size/shape and buoyant density. In our experience it has shown itself to be an especially reliable procedure for the rapid morphological identification of new virus isolates from cell culture. Only small volumes of material are required; with the development of cytopathic effect in a single culture tube, enough material is provided not only to passage the isolate onto
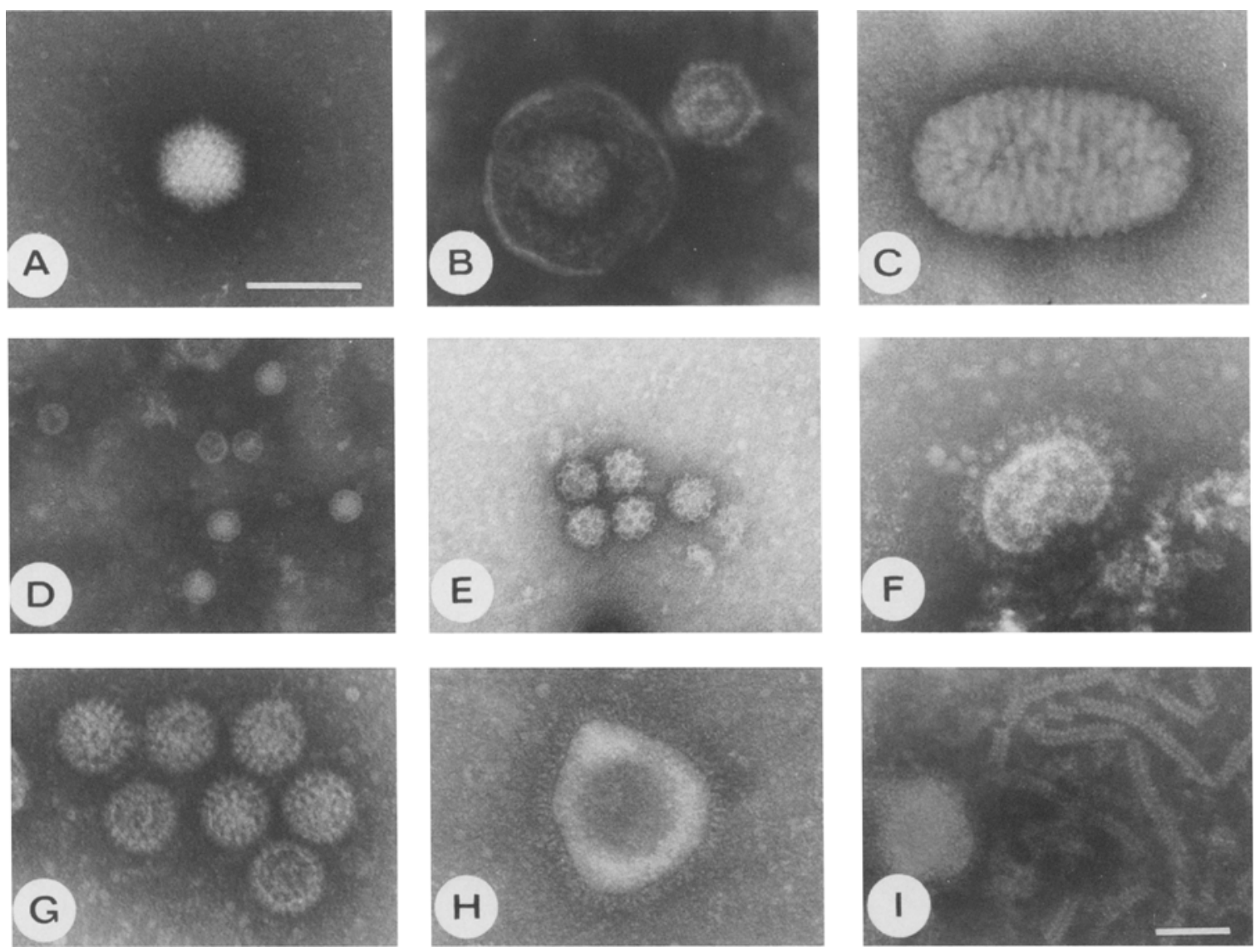

FIK. 1. Representative examples of selected virus families, as revealed by NCEM. A, Adenoviridae (No. WADDL 825536-12). bovine, from bovine turbinate cell culture; $B$, Herpesviridae ( $N$ o. M255T), bovine. from calf kidney cell culture: $C$, Poxviridae ("Pandora"), cetacean, from cutaneous lesion: $D$, Picronaviridae (No. OSU 475R), bovine, from calf kidney cell culture; $E$, Caliciviridae (No. SDZ 041), cetacean, from Vero cell culture; $F$, Coronaviridae (No. M254T). bovine, from calf kidney cell culture; $G$, Reoviridae (No. OSU 568R), bovine, from tovine turbinate cell culture; $H$, Paramyxoviridae (No. M14CN), bovine, from calf kidney cell culture: I, Paramyxoviridae (No. OSU 463CN), bovine, from Vero cell culture, illustrating typical "herringbone" nucleocapsid. Bars $=100 \mathrm{~nm} . A$ through $H, \times 108571 ; I$, $\times 81$ 905. Isolate $A$ prepared from material kindly provided by Dr. J. F. Evermann. Washington Animal Disease Diagnostic Laboratory, Washington State University, Pullman, Washington. 
fresh monolayers but also to examine it by NCEM at the same time. In many cases we used this technique in conjunction with immune electron microscopy for preliminary serologic identification of isolates. It is useful for the identification both of cytopathic and noncytopathic isolates, and we have obtained successful results by direct examination of clinical specimens, including feces and skin scrapings (Fig. $\mathrm{l}$ C). The success of the procedure lies in part in the intermediate centrifugation step $(2500 \times g$ for $10 \mathrm{~min})$, which effectively cleans the preparation by removing most of the nonviral, particulate (cellular) debris remaining after preliminary clarification. Of corresponding significance is the final, moderate-speed centrifugation step $(8850 \times g$ for $20 \mathrm{~min})$ which we have found to be most effective for pelleting many viruses and a desirable alternative to ultracentrifugation. The resulting pellets have produced clear, even spreading of virus particles on grids, with minimal amounts of unwanted virion aggregation ("clumping"), background staining, and subcellular debris (a frequent contaminant of ultracentrifuged preparations). Importantly, the ultrastructural integrity of most virus particles has been well preserved.

The major advantages of NCEM that have been cited traditionally are its speed, simplicity, and capability of identifying viruses on a morphological basis without the need for intermediate, specific reagents $(1,2,6,7,12)$. Its major disadvantage is a relative insensitivity when compared to certain other techiques, such as enzyme immunoassay, radioimmunoassay, or virus isolation $(1,2,22)$. Because of this, various preparatory procedures for concentrating virions from sample material have been described. These have included ultracentrifugation $(3,7,8,19,20)$, pseudoreplication $(10,16)$, density gradient centrifugation $(4,9)$, immune electron microscopy $(1,6,14,19,21,23)$, ammonium sulfate precipitation (5), and polyacrylamide hydrogel absorption (22). Some have concentrated viruses by simple low-speed centrifugation $(13,17)$, although the validity of this type of procedure has been questioned (18). Of all these methods, ultracentrifugation has received without doubt the widest acclaim and acceptance for rapid viral diagnosis $(1,6-8$, $11,17)$. However, ultracentrifugation is not without its own disadvantages (sedimentation time, disruption of virion morphology, cosedimentation of subcellular debris, requirement for ready access to an ultracentrifuge) $(9,15,20,22)$. With the procedure described in this report, the need for a relatively prolonged ( 1 or 2 h) ultracentrifugation step has been eliminated, decreasing sample manipulation and resulting in even greater simplification of the process. Importantly, the time required for the preparation of samples has been reduced considerably. Search time for the location and identification of isolates with the electron microscope has been minimized (usually averaging less than $1 \mathrm{~min}$, frequently much less) by the fine, even quality of the final preparations. Although some degree of virion loss is inevitable in the two lower-speed centrifugation steps, this had had little effect on our ability to rapidly locate and identify isolates from cell culture supernatants. This procedure will probably prove useful for the detection and identification of a broad range of virus isolates in addition to those described in the present communication.

\section{REFERENCES}

1. Almeida. J. D. Practical asperts of diagnostic electron microscopy. Yale J. Biol. Med. 5:3:5-18; 1980.

2. Almeida, J. D. Rapid viral diagnosis hy electron microscopy. Scand. J. Infect. Dis. [Suppl] :36:117-120; 1982.

3. Berry. E. S.; Shea, T. B.; Gabliks, J. Two iridovirus isolates from Carassius auratus (L.). J. Fish Dis. 6:501-510: 1983

1. Burroughs. J. V.: Doel. T. R.; Smale. C. J. et al, A model for vesicular exanthema virus, the protolype of the calicivirus group. J. Gen. Virol. 10:161-171:1978.

5. Caul. E. 0.: Ashley, C. R.: Egglestone, S. I. An inproved method for the routine identification of fecal viruses using ammonium sulfate precipitation. FEMS Microbiol. Lell. 1:1-1: 1978.

6. England, J. J.: Reed. D. E. Negative contrast electron microscopic techniques for diagnosis of viruses of velerinary importance. Come. Vet. $70: 125-136 ; 1980$

7. Flewett. T. H.: Bryden. A. S.: Davies. H. Diagnostic electron microscopy of faeces. I. The viral flora of the faeces as seen by electron microscopy. J. Clin. Pathol. 27:603-614: 1974.

8. Hammond. G. W.: Hazelton, P. R.: Chuang, I. et al. Improved detection of viruses by etectron microscopy after direct ultracentrifuge preparation of specimens. J. Clin. Microbiol. 14:210-221: 1981.

9. Horzinek, V. C.: Osterhaus, A. D. M. E.; Ellens, D. J. Feline infectious peritonitis virus. Zentralbl. Veterinamed. [B] 24:398-405: 1977.

10. Lee, F. K.; Vahmias. A. J.: Slagno, S. Rapid diagnosis of cylomegalovirus infection in infants by electron matroseops. N. Engl. J. Med. 299:1260-1270: 1978 .

11. Madeley, C. R. Comparison of the features of astroviruses and caliciviruses seen in samples of feces by electron microscopy. J. Infect. Dis. $139.519-523 ; 1979$

12. MeFerran, J. B.: Clarke, J. K.: Curran. W. L. The application of negative contrast electron microscopy to routine veterinary virus diagnosis. Res. Vet. Sici. 12:25:257: 1971.

13. Narang. H, K.: Codk. A. A. A low-speed centrifugation terhnique for the preparation of grids for direct virus examination by efectron microscopy. J. Clin. Pathol. 32:301-305; 1979.

14. Narang. H. K.: Codd, A. A. Enterovirus typing by immune electron microscopy using low-speed rentrifugation. J. Clin. Palhol. 33:191$194 ; 1980$.

15. Polson. A. New approaches 10 ultracentrifugation. In: Maramoroscl, K.: Koprowski, H. eds. Methods in virology, wol. V. Vew York: Academic Press: 1971:3:3-77.

16. Portnoy. B. L.; Conklin. R. H.: Mem. M. et al. Reliable identifination of reovirus-like agent in diartheal stools. J. Lat. Clin. Ved. 89:500 $563 ; 197 \%$.

17. Rice, S. J.: Phillips. A. D. Rapid preparation of faecal specimens for detection of viral particles by electron microscops. Med. Lab. Sci. $37: 371-372: 1980$. 
18. Rodgers, F. G. Detection of rotavirus particles from patients with gastroenteritis. Lancet 1:1360-1361: 1980.

19. Smith, A. W.: Skilling, D. E.: Ritchie, A. E. Immunoelectron microscopic comparisons of caliciviruses. Am. J. Vet. Res. 39:1531$1533 ; 1978$.

20. Stoddart, C. A.; Barlough, J. E.; Scott. F. W. Experimental studies of a coronavirus and coronavirus-like agent in a barrier-maintained feline breeding colony. Areh. Virol. 79:85-94; 1984.
21. Whitaker, H. K.: Alderson, C. The use of negative contrast electron nicroscopy (NCEM) for diagnosis of viral infections in animals. Annu. Proc. Am. Assoc. Vet. Lab. Diagnost. 23:321-350: 1980.

22. Whitby, H. J.; Rodgers, F. G. Delection of virus particles by electron microscopy with polyacrylamide hydrogel. J. Clin. Pathol. 33:184$187 ; 1980$.

23. Zissis. G.: Lambert, J. P.; DeKegel, D. Routine diagnosis of human rotaviruses in stools. J. Clin. Pathol. 31:175-178: 1978.

10) Sarstedt, Inc., Princeton, VJ.

11 Millipore Corp. . Bedford, MA.

12 American Can Co., Greenwich. CT.

13 Ted Pella Co., Tustin, CA.

1t Electron Microscopy Sulences, Ft. Washington. PA

is Whatman Lid., England.

16 GTE Sylvania, Inc., Danvers, . $\mathrm{A}$.

${ }^{17}$ Philips Electronic Instruments. Inc.. Mahwah, NJ.

${ }^{8}$ Forma Scientific, Marietta, OH.

${ }^{9}$ International Equipment Co., Needham Heights, MA.

Oregon Agricultural Experiment Station Technical Paper No. 7358.

Supported by the Oregon Agricultural Experiment Station, Project No. 785. 